University of Wollongong

Research Online

Centre for Multicultural Studies Occasional

Papers

Faculty of Arts, Social Sciences \& Humanities

1987

\title{
The bicentenary and the failure of Australian nationalism
}

\author{
Stephen Castles \\ University of Wollongong \\ Bill Cope \\ University of Wollongong \\ M Kalantzis \\ University of Wollongong \\ M Morrissey \\ University of Wollongong
}

Follow this and additional works at: https://ro.uow.edu.au/cmsocpapers

\section{Recommended Citation}

Castles, Stephen; Cope, Bill; Kalantzis, M; and Morrissey, M, The bicentenary and the failure of Australian nationalism, Centre for Multicultural Studies, University of Wollongong, Occasional Paper 5, 1987, 18. https://ro.uow.edu.au/cmsocpapers/5 


\title{
The bicentenary and the failure of Australian nationalism
}

\author{
Abstract \\ This article is an excerpt from the book: Mistaken Identity - Multiculturalism and the Demise of \\ Nationalism in Australia, published by Pluto Press, Sydney in February 1988. This excerpt concentrates on \\ the ideological side of the issue. The book also deals with the material basis of nationalism and its \\ relation to developments in the political economy of world capitalism, and of Australia.
}


THE CENTRE FOR

MULTICULTURAL STUDIES

-

UNIVERSITY OF WOLLONGONG 
The Bicentenary and the

Eailure of Australian

Nationalism

S. Castles, M. Kalantzis,

B. Cope, \& M. Morrissey

Occasional Paper No.5

\title{
THE BICENTENARY AND THE FAILURE OF AUSTRALIAN NATIONALISM
}

\author{
Stephen Castles \\ Bill Cope \\ M. Kalantzis \\ M. Morrissey
}

This article is an excerpt from the book: Mistaken Identity Multiculturalism and the Demise of Nationalism in Australia, published by Pluto Press, Sydney in February 1988. This excerpt concentrates on the ideological side of the issue. The book also deals with the material basis of nationalism and its relation to developments in the political economy of world capitalism, and of Australia.

\section{CENTRE FOR MULTICULTURAL STUDIES UNIVERSITY OF WOLLONGONG}

P.O. Box 1144 Wollongong, NSW 2500 Australia

Phone: (042) 270780 
By international and historical standards, Australia is a very quiet place. Despite this appearance, things of world-historical significance have happened here. Few conquests have been so systematic and brutal as that of Aboriginal society. Here our quiet is deceptively a product of the very severity of the conquest and consequently, an active silencing of historical guilt and possible arguments about reparations. The other event of world historical importance is Australia's post-war immigration. Again, the quiet of this place deceives. It has been a programme of incomparable size internationally in the past half-century: a first world society with low birth rates has doubled its population, to a significant extent through immigration, in forty years. No other nation-state has been as actively involved in the recruitment of immigrants. Nowhere have the sources of immigrants been so diverse.

\section{Defining Australia}

Settler colonialism and mass immigration gave a special flavour to attempts to construct an ideology of the Australian nation. According to Benedict Anderson, 1987 was the 200th anniversary of the birth of the nation state. The "extraordinary invention" which was to become an "unproblematic planetary norm" came to the world, says Anderson, in the shape of the Constitution of the United States of America. ${ }^{1}$ The nation whose 200th anniversary we are called upon to celebrate in 1988 was founded just one year later. That would make it the first completely modern nation.

This view of Australia may put quite a strain on our credulity: did the convicts know they were coming to found a nation? Did they want to? Do the descendants of the Aborigines who saw the First Fleet land see things that way? Was a nation founded at all? After all, our monarch still lives overseas; many of our basic institutions are imported from our former Imperial ruler. If so, when was it founded? In 1788, in 1901 at the time of Federation, with the Statute of Westminster in 1928 or when appeals to the Privy Council were abolished in the mid-1980s? But what is a nation anyway, in a world in which crucial economic and political decisions are no longer made at the national level, especially for the smaller states?

It is necessary to grapple with some of the more significant recent attempts at making nationhood. In particular, we want to look at the effort to define the Australian nation as "multicultural", which began in the early 1970 s, and continues, despite some controversy, to enjoy the support of all major political forces.

Multiculturalism is an ideology which calls for a celebration of cultural diversity, as an ongoing feature of Australian society. 2 It thus appears as a departure from previously prevailing racist and nationalistic stereotypes of the nation. But this progressive move bears problems: how is the tension between ethnic pluralism and the cohesiveness of society as a 
whole to be resolved? How can a nation be defined, if not in terms of ethnic identity: shared history, traditions, culture and language? How are core values and acceptable behavioural forms to be laid down, if the dominance of Anglo-Australian culture is no longer accepted? The problems of a multi-ethnic state are neither new nor unique in the world, but the response of multiculturalism is certainly a new departure in the history of Australia. So we must ask what multiculturalism means, and if it is a viable way of defining the nation.

But we must also ask if it is to be taken at face value. Has it really changed the ethnocentric structures which are so entrenched in every area of Australian life? Is it even meant to? It is also seen by some as a form of social control, a way of incorporating ethnic middle classes into the Australian political system, and using them to control their less successful compatriots, at a low cost to the state. ${ }^{3}$

The year 200 is a good moment to discuss attempts to define the nation, for the most obvious of these attempts is the Bicentenary itself. The Bicentennial Authority has been working for nearly a decade to:

... "plan, co-ordinate and promote a year long programme of local, national and international activities and events to celebrate Australia's Bicentenary and to involve 16 million Australians in the celebrations and events of 1988".4

As a planned, state-run exercise in the creation of a national idea, the Bicentenary is almost without precedent: for a whole year we are called upon to "join in the activities of 1988 and to celebrate what it means to be Australian". 5

The Bicentenary is to be multicultural. We are told that "Australians will really be "Living Together" in 1988". The Bicentennial Authority has developed a "set of planning objectives" to achieve this:

To celebrate the richness of diversity of Australians, their traditions and the freedoms which they enjoy.

To encourage all Australians to understand and preserve their heritage, recognize the multicultural nature of modern Australia, and look to the future with confidence.

To ensure that all Australians participate in, or have access to, the activities of 1988 , so that the Bicentenary will be a truly national programme in both character and geographic spread.6

There we have it: we must be multicultural to be national. And how shall we do it? The Authority tells us:

Plant shrubs, hedges and trees... make community litter bags... Re-enact an episode from your district's past... Make a census of the headstones... Organize an Australiana Trivial Pursuit Game... Bake an Australia-shaped cake for a raffle... Plan to have a meal from a different culture at 
least once a month in 1988... Paint a giant Bicentennial Living Together sign... 7

But whatever you do, don't remind the public of unpleasant realities. In 1987, the Bicentennial Authority asked Ms. Franca Arena, a NSW State Labor MP and Justice Michael Kirby, President of the NSW Court of Appeal to write articles for its glossy journal Bicentenary 1988. Ms. Arena wrote of migrants' encounters with "racists, bigots and intolerant people", and called for Australia to become a republic, since the monarchy was meaningless for many Australians. Justice Kirby described the unjust, destructive and discriminatory impact of the legal system on Aboriginal culture, and drew attention to concern about the disproportionate number of Aboriginals in jail. Their articles were rejected. Our image of multicultural Australia is meant to be at the level of Trivial Pursuit: song and dance, food and folklore.

The Bicentenary itself is likely to be forgotten soon enough. It is one of history's one-night stands. But it is part of a long tradition of attempts to define Australia, and what it means to be Australian. Why is there such a need to do this? Donald Horne has pointed to the process of "realitycreation" required to establish new nation states:

"There are many characteristics a new nation-state might be seen as having. Only some of them prevail. In the processes that precede the formation of new nation-states great acts of imaginative construction occur, out of which the new nation is born". 8

There is no doubt that the creation of a national ideology is part of the political process of establishing the nation. The question of which national characteristics prevail, depends on the balance of social forces within this process. Those who have the power to create and rule a nation-state, have the most influence in defining the "national character". The definition may embody abstract ideals (liberty-equality-fraternity) and it might satisfy a popular desire to "belong", but is linked just as much to the economic and political interests of the definers.

Now, if we are to follow Anderson, we all belong to "new nations", for all modern nations are a product of the last two centuries, being closely linked to the economic and political processes of world development. 9 Nor is the "reality creation" of the national character something that happens once, at the beginning of a new nation. 10 Rather there is a constant process of asserting, questioning, re-defining and examining the national identity. As Horne writes:

"The great drama, endlessly playing, is that of maintaining definitions of the nation and its social order: definitions are being repeated daily, hourly, of what the nation and society are." 11 
So Australia's definers are doing what those of all nations do, when they put forward a national image. But they seem to do with more regularity and fervour. Richard White starts his book on "Inventing Australia" by calling it "the history of a national obsession". He points out that "Australia has long supported a whole industry of image-makers to tell us what we are". 12 White does not tell us why Australia should be a forerunner in this field. We may speculate that the cause lies in some of the ambiguities of the Australian condition. In seizing what they called empty land, the colonists denied the humanity of their Aboriginal predecessors' very existence. For the white invaders, there was no history before 1788 . This Australian nationalism had to start from a year zero, or it has to regard itself as part of the history of the"British race".13 Australia grew as part of the British Empire. Unlike the USA, India or Britain's other far-flung possessions, Australia never managed a decent independence movement, let alone a liberation struggle. Australia was made a nation by an Act of the British parliament in 1901. The creation of a nation in a struggle for independence is usually the pre-eminent moment for the definition of national character, language, culture and myths. Australia has missed out on this, and has therefore had to make a more conscious effort to define itself. The task has not been made easier by its geographical position. On the other side of the world from its "mother country" and sitting on the edge of Asia, the maintenance of Britishness put a strain on resourcefulness and imagination, especially as Britain's economy has faded and its Empire has crumbled.

White has documented the changing attempts to define the "Australian type": the muscular sunburnt bushman, the "Coming Man", whose selfreliance and physical prowess would renew the British race, the Digger, who proved himself at Gallipoli, the Bondi lifesaver:

The emphasis was on masculinity, and on masculine friendships and team-work, or "mateship" in Australia. All the clichés - man of action, white man, manliness, the common man, war as a test of manhood - were not sexist for nothing. Women were excluded from the image of the "Coming Man", and so were excluded from the image of the Australian type as well. 14

Being Australian has always been defined in sexist terms. It has also been defined in racist terms. In the early days, the pioneers' battle against the hard land was also seen as a struggle against the dangerous and wily blacks. Later the fight was against migrants who would dilute the British character of the nation, and undermine the race. The main threat was the "yellow peril" and above all the Chinese who started coming in the mid19 th century. But there was hostility towards all "non-Britishers". One of the first Acts of the new parliament in 1901 was to pass the Immigration Restriction Act, designed to keep out non-European immigrants, and 
popularly known as the White Australia Policy. Humphrey MacQueen has drawn attention to the role of racism in the construction of the Australian labour movement. 15 The restriction of immigration and the call for a white Australia were themes which had mobilized workers and their organizations - the unions and the Australian Labor Party in the latter half of the 19th century and which would continue to do so until the Second World War.

The Immigration Restriction Act was not generally used to keep out European settlers, although they were relatively few in number until 1947. Those who did come encountered considerable hostility. Australian workers were often unwilling to work with them. In the isolationist mood of the Depression era, attempts were made to exclude non-British migrants, and to combat the influence on other cultures within Australia. At Kalgoorlie in 1934 several people were killed in "anti-dago" riots. 16 Attempts by employers to employ new migrants at low wages or to recruit them as strike breakers did not help matters.

So the Australian type was constructed in terms of the white, masculine outdoor person originating from the British Isles. Even that was contradictory enough in the light of the struggles between English and Irish. These came to a head during the First World War in the context of the Irish fight for Independence and the conflict on conscription in Australia. The concept "Anglo-Celtic", commonly used in debates on multiculturalism today, is an ill-conceived monstrosity, which can only partially paper over the gulf. One of the problems of defining the Australian nation is that its supposed sub-stratum - the British nation does not exist either. There is indeed a British nation-state, but it uneasily embraces at least four nations (or ethnic groups). 17

There is, however, another side to the Australian type which was being constructed before 1945. The muscular bushman/digger/life-saver was working-class. He was a "battler", who did not take kindly to authority. It was a populist image, that fitted into the concept of Australia as a "workers' paradise", where there were no aristocrats, where there was no entrenched privilege, where everyone had a chance of success. This side of the Australian type is summed up in the ideas of "mateship" and "a fair go".

How realistic was the image? From the earliest days, of European settlement, there was a strong measure of inequality in Australia. A landed oligarchy developed rapidly, and later merged with trading and manufacturing interests. There were class struggles throughout the 19th century, with the high demand for labour in the boom following the Gold Rush giving impetus to labour organization. The wealthier classes' demand for immigrant workers, and the existing working class' fear of dilution of labour were central political themes for much of the 19th century. 18 Contrary to ideas of the open frontier and individualism, the state played a central role in Australian development. First it was the British Imperial state, later the governments of the states and the 
Commonwealth, but always there was a high degree of bureaucratic control. The idea of the individualistic bushman is clearly ambiguous. On the one hand it was an attempt to assert populist values against the ruling class and the state. On the other, it was an officially propagated image, useful to conceal the reality of a highly stratified, bureaucratized and increasingly urbanized society. Crocodile Dundee has had many predecessors.

Australia's self-image, therefore, has always been problematic. It has been racist, justifying genocide and exclusionism, and denying the role of non-British migrants. It has been sexist, ignoring the role of women in national development, and justifying their subordinate position. It has idealized the role of the "common man" in a situation of growing inequality and increasingly rigid class divisions. It has been been misleading, in its attempt to create a British/Australian ethnicity, while ignoring the divisions with the British nation-state, and its Australian offshoot.

But for all that, the image might have been maintained, had it not been for Australia's post-war immigration programme. The mass settlement of migrants from a wide range of countries has made the overt maintenance of a racist definition of the nation and of the Australian type impossible. Today, an attempt is being made to re-interpret the immigration programme as a deliberate move towards a multi-ethnic society. That is far from the truth: immigration was seen in the mid-1940s as a strategic necessity to make the country economically and militarily strong enough to repel the "yellow peril". No ethnic diversity was intended: British migrants were wanted, and when they could not be obtained in adequate numbers, the call was for "assimilable types" who would rapidly become indistinguishable from other Australians.

\section{Constructing Nationalism}

But cultural assimilation did not take place. Australia became a country with at least 80 different ethnic groups. If the idea of a nation and of a national type is needed to secure social cohesion, then Australia is faced with a new problem: how to define these in a non-racist and non-monocultural way.

According to Ernest Gellner:

...nationalism is a theory of political legitimacy, which requires that ethnic boundaries should not cut across political ones, and in particular, that ethnic boundaries within a given state... should not separate the powerholders from the rest. 19

In other words, nationalism is based on the idea that every ethnic group or nation should have its own state, with all the appropriate trappings: flag, army, Olympic team and postage stamps. People relate to these symbols. A feeling of nation-ness is an integral part of their lived experience. But 
what happens when the people of a nation-state consist of more than one ethnic group with different symbols and lived experiences? This is a common enough situation, but in the nationalist view of the world, it is likely to lead to conflict. As soon as people become conscious of their destiny as a nation they will either subjugate the other ethnic groups within the state boundaries, or, if they belong to a minority, they will fight for their own state.

Pre-industrial states, including the greatest empires, were held together not by national feeling, but by a system of power, symbolized by the divinely appointed monarch. For a colonial subject, loyalty to the British Crown had nothing to do with ethnicity. The modern nation-state, in its ideal form as a democratic republic, cannot exist on this basis. Since power belongs to the people, and is only delegated to the state (in its classical triad of legislative, executive, judicative), legitimacy cannot rest on loyalty to the state. The state is an instrument of the people; being loyal to it as a tautology. Legitimacy is based on the will of the people, and that makes it imperative to know clearly who constitutes the people: "Nationalism is primarily a political principle, which holds that the political and national unit should be congruent." 20 The struggles to make the state and the nation congruent have been at the root of much of the slaughter of our century.

In fact there are very few countries today which are ethnically homogeneous. The process of industrialization and modernization leads to larger state units, embracing a variety of ethnic groups. There are few advanced countries without their "old" minorities such as the Bretons in France, the Basques and Catalans in Spain. Sometimes this often develops into serious clearage as in Italy and in Britain. Moreover, the process of development almost always involves rural-urban migrations which quickly transcend national boundaries: in the 19th century the Irish came to Britain, the Poles to Germany, the Italians to France and Switzerland, and people from all over Europe to the USA, Canada, and some South American countries. Since 1945, there has been large-scale labour migration to most Western European countries, to North America and Australia, leading to the development of significant new ethnic minorities throughout the First World.

In encouraging labour migration, the states concerned followed shortterm labour market interests, with little consideration of the long-term consequences. There was certainly no desire to create multi-ethnic societies. Now that this has happened, there are various responses: laisserfaire, state racism or exclusionism, assimilationism, and multiculturalism. Whatever policy is followed, a new situation has to be dealt with: membership of the collectivity is no longer simply a result of birth; the boundary of the collectivity cannot easily be defined according to a myth of common origin or fate. If nationalism is a crucial social ideology then a new way must be found to define the nation. Nowhere is this problem more pressing than in Australia, where the post-war migrations 
have been so large in scale, that they have transformed the ethnic composition of the population. Forty percent of the Australian people today are immigrants or children of immigrants. Half of these are of nonBritish origin.

Sixty years ago, J. Lyng could write:

The position can be compared with that of a river, started by a small spring in the mountains, winding its way through unknown country, gaining in volume and importance as it flows along, till, at the end of its course, it has become a mighty stream with incalculable potentialities. Here and there the river is made slightly bigger by tributaries. 22

The river was "English language", "English culture" and "British stock" (an interesting juxtaposition). The tributaries were the most "modest contributions" of "non-Britishers". Even in the 1950s it was possible to assert:

Our life is still British wholecloth, so to speak, and though the warp-threads may have turned a little, they are still strong; we have only coloured and arranged the weftthreads a little differently. 23

With hindsight, we can say that such a view of the world was ethnocentric and mistaken even then. But it did provide a workable basis for a national ideology.

That ideology could not survive the fundamental changes resulting from the crumbling of the British Empire, the post-war immigration programme and increasing vocal claims by Aboriginal groups. What were the alternatives? Other new, immigrant nations have had to contend with this problem. It is easy to understand the concepts that can hold the USA together, without recourse to ethnic identity: they include the revolutionary tradition, the force of new universalistic ideals, the strength of the "American way of life", the fascination of world power, the integrative force of modernism and innovation. Australia can only aspire to such ideals in an imitative, second-rate way. In the 1950s, attempts to define the nation focused on "the Australian way of life". The image was one of a prosperous suburban society, in which every man had his house and garden, his Holden and his hobby. Again it was a sexist image, centred around the man as bread-winner for a neat and happy nuclear family. 24

It was a new image, that could compete with increasingly irrelevant Anglo-centric traditions. And it could draw in the New Australians: you did not have to come from Britain to want a Holden and a house, to be a good worker and trade unionist, and to support the idea of a fair go. Consumerism matched the idea of assimilationism: to be Australian meant simply to conform in terms of work and life-style. The ideology of "the Australian way of life" appeared as the pinnacle of modernism: pride in 
economic progress, technical advance and a high standard of living was to make differences in origin, race and ethnic background meaningless.

\section{The Rise of Multiculturalism}

But by the 1970s, this approach was failing, and there was a need for a new national ideology. There were several reasons for this. First, the modernist, assimilationist principle had only scratched the surface of a society still highly elitist and dominated by Anglocentric values. Second, the onset of recession and restructuring of the world economy was making Australian living standards vulnerable. Third, trends towards economic and social segmentation linked to race, ethnicity and gender were making the whole concept of the "Australian way of life" questionable. The idea of of "multiculturalism" was an attempt to modify existing concepts of the nation to match up to the new realities.

Whitlam's Minister of Immigration, Al Grassby, announced his version of a "multi-cultural society of the future" in 1973. The Labor Government made efforts to take account of "migrant needs" in its social policies. From 1975, Fraser's neo-conservative government took up the slogan, and by the end of the decade had worked multiculturalism up into a full-blown ideology for the Australian nation. Multiculturalism has been embraced by the Hawke Labor Government, which was elected in 1983, and by the various state governments, and remains a multi-party concensus.

Australian multiculturalism has two facets. The first is "ethnic politics", which began as part of a programme of social democratic reform. As such it was not without its intrinsic merits. In the area of education for example, specialist English-as-a-Second-Language teaching was a genuine attempt to right the specific disadvantage suffered by children of non-English speaking background. Multicultural policy in education prescribed social reform, based on an understanding that some groups are disadvantaged. Cultural patterns, viewed by "ethnic politics" as group life-chances and wider structural relations, needed to be changed.

The second facet is the social policy of "cultural pluralism" which came to be the official embodiment of the multicultural response to ethnic politics as neo-conservatism gained sway. In some senses cultural pluralism did almost the opposite of ethnic politics. It did not set out to reform society. It merely wished to describe society as it was in order to celebrate its diversity.

For cultural pluralism the culture in multiculturalism must be those things which "already exist" in diversity": the "interesting" and the "colourful", personal "lifestyles" and "relationships", "identifications" and "points of view". These belong to "the essentially private domain of family and religious belief".25 This world is also the realm of "folk art ..., dancing, music, craft and literature ... ." 26

In some senses, "ethnic politics" and cultural pluralism are at odds. The two views, however, often exist simultaneously in self-contradiction. On the one hand, the focus is on getting into the same cultural act as the 
dominant groups. On the other hand, the focus is on maintaining the diversity (which often, and perhaps conveniently, happens not to be a diversity of social equals). On the one hand, there are de-facto arguments for structural assimilation without tears (with the cultural imperatives and ethos that accompany this). On the other hand, there is an ideology of pluralism, implacably hostile to any suggestion that assimilation might be going on. On the one hand, there is a view that migrants are "disadvantaged" and need to learn new cultural skills which open up mobility opportunities. On the other hand, the same thing is called "diversity" which is to be cherished and left alone. On the one hand, social prescription is a rationale for reform. On the other hand, social description is a celebration of what is.

But, having said this, there are also elements of consistency to be found between ethnic politics and cultural pluralism. First, cultural pluralism is a handy and inexpensive solution to the problem of ethnic politics. Second, both cultural pluralism and ethnic politics transpose, albeit by slightly different logics, debates about the plight of minorities from a realm which might in part involve critical structural analysis, to an analysis simply of "culture" or "ethnicity".

The most fundamental question then, is why bother trivializing the notion of culture? Whatever the inadequacies of a theory, such as the reformist vision of ethnic politics, which tries to give all social groups tickets in the lottery of social mobility, at least it admits social disadvantage and wants to find ways of righting it. But when the multiculturalists attempt to discuss what they mean by the culture we can find in diversity, they shift from social prescription to social description, from the imperatives of reform to a celebration of what exists. At best, multiculturalism is an escape, a consolation for "the increasing alienation of the individual from the complexities and pressure of modern society. The nation is simply too large, too amorphous, too remote and impersonal to offer a satisfactory basis for wider relationships". 27 Cultural pluralism in other words can help overcome or prevent the insecurity, homogenization and loss of personal identity characteristic of mass society. It is possible to retreat into culture narrowly defined. But there is a sense in which this is precisely the effect of that brand of ethnic politics which merely sees multiculturalism as the removal of "cultural" or attitudinal barriers from minority groups to play the core cultural game, which remains fundamentally unquestioned.

\section{The New Right and the Attack on Multiculturalism}

Multiculturalism has been attacked recently in the media. We find both the old-style racist populism of Geoffrey Blainey (a prominent historian) and of Bruce Ruxton (President of the Victorian branch of the Returned Services League), and the more subtle racism of the so-called New Right. The focus of debate has been the increasing proportion of migrants who come to Australia from Asia. 
The "New Right" recognizes and abhors the crisis of unitary national identity. It puts this down in large measure to the destructive influence of a "new class" of trendy left intellectuals and public servants. By the late 1980s, wrote David Barnett in the news magazine The Bulletin, there were thousands of government employees in the multicultural industry with a "vested interest in perpetuating separate ethnic identities". The perceptions of this "New Right" are frequently very shrewd, even if their call for "Anglomorphy" (following English values and life-styles) is a rather bizarre aspiration for Indo-Chinese immigrants, in contra-distinction to the somewhat different aspiration to success in the competitive world of wage labour and commodity production. "Hard multiculturalism", in order to preserve "ethnic integrity", it is pointed out, is equally liable to assist in the reproduction of traditions and values that often grotesquely ignorant and both racist as sexist. 28 Furthermore, as L.J.M. Cooray argues in the New Right journalQuadrant, multiculturalism is based on a "retrogressive conception of culture", static and seeking to retard, naively against against inevitable pressures, the process of cultural interaction and evolution. 29

Both the populists like Blainey and the intellectual "New Right" represent revived versions of a racist conception of Australian identity. At the most fundamental level, both Blainey and the "New Right" recommend an ideology of unitary identity and self-assurance about the superiority of the industrial society we live in. Partly reminiscent of the glories of English colonial ideology, both inject an element of English-ness into their characterization of this society. Both advocate assimilation as the most desirable approach to cultural difference. In articulating these views, they advocate a return to the past, in critical appraisal of the development of multiculturalism and cultural pluralism generally. These are the roots of their brand of racism.

At more superficial levels, Blainey falls into modes of discourse which are more immediately and inevitably racist. Diagnosing as he does the visible phenotypical and cultural differences of "Asian"-ness to be the significant problem of racism, both in nineteenth century Australia and today, is to accept at face value the racist interpretative framework of some of the historical and social actors. Rather, visible differences are not themselves the problem. The problem is the ideology of racism as a means of (mis)-interpreting social division. Blainey follows those social actors he considers to be significant into the misconception of a supposed reality of "race" as the problem rather than "racism" as ideology.

The "New Right", on the other hand, whilst equally convinced of the virtues and supposedly inevitable realities of assimilation, evidently think the cultural difference of "Asian"-ness less great than Blainey and thus that "Anglomorphy", for any immigrant convinced of the virtues of the free enterprise society, is a viable and desirable process. Of course, in this there are very obvious assumptions about the incompatibility and undesirability of on-going cultural difference, in which frequently racist assumptions are not so deeply submerged. 
Blainey and the "New Right" are not simply temporary and unpalatable social commentators. They reiterate the official policy and the dominant popular ideology of the decades up to the mid-1970s and reflect some fundamental structural and cultural processes which still persist, despite some of the pretensions of the happy ideology of cultural pluralism of the 1980s.

\section{Options for Australia}

The dilemma is evident: the now dominant paradigm of Australia as a multicultural society will not sustain a nationalism able to perform its traditional ideological function. Put simply, the project of imagining communality, imagining the shared mission of the nation, imagining our domestic progress as all of us move simultaneously through history, is torn apart by the paradigm of cultural difference that replaces assimilation. Apart from the material fact that we can no longer believe strongly in the reality of that progress, we now also imagine formally equal and culturally relative differences, of ethnicity, gender or "lifestyle". But the "New Right" project of advocating a revival of nationalism as a way of resolving our social and economic woes is equally problematic: Its assimlationist assumptions have failed in the past, and will continue to fail due to the demographic diversity and socio-economic segmentation of Australian society.

Equally important in causing the breakdown of Australian nationalism is the growing internationalisation of the economy. The decisions which determine Australian living standards and income distribution are today made on the stock-markets of Tokyo and New York, rather than by Australian governments. International commodity design and production and improving communications in turn cause an erosion of national lifestyles and cultures. These themes cannot be pursued further here.

So what possibilities are available to Australia as we enter the third century of white settlement? We see four options:

1) Inequality plus imagined community

This means the continued integration of the economy as part of the world market, but with the development of a strong ideological basis for national identity, leading to a general commitment to the Australian nation-state. This option, as spelt out by the "New Right" seems highly unlikely to succeed, given the problems of Australian national identity described. Attempts to create a general "we-feeling" through sport, life-style symbols or indeed through the Bicentenary have had no enduring success. 2) Inequality plus state repression

This is the "Latin American" model, in which social and political divisions become too sharp to be accommodated in concensus-type parliamentary politics. If the Australian economy really moves into the "Banana Republic" mode envisaged by Treasurer Keating in 1986, and no equitable way of sharing the burden can be found, so that the billionaires get richer and the number of people in poverty grows, then a peaceful 
solution may not be possible. Under similar pressures, formally democratic states in Latin America (Chile, Uraguay) succumbed to military dictatorships in the 1970 s. This option seems possible, but not likely, for concensus politics have certainly not broken down here yet.

3) Inequality plus fragmentation and quiescence

In this option the breakdown of social solidarity takes the form, not of polarization, but of fragmentation. Politics becomes increasingly meaningless, as the lack of real power of parliaments can no longer be concealed. Since the decisions are made in the stock exchanges of Tokyo, London and New York, and in the international corporate bureaucracies, why bother anyway? The result is hopelessness, hedonism and retreat into the private sphere. Protest takes the form of life-styles and sub-cultural pressure groups, and can easily be co-opted by the leisure industries. Increasing drug and alcohol addiction, fundamentalist religion, mental illness and violence are products of the real powerlessness of the social being. Politics shift from interests to values, providing a focus for "New Right" ideologies of family, individuality and competition. This seems the most likely scenario of all, for it is simply an extrapolation of existing trends.

\section{4) Equality plus real communality}

An alternative to these less than inspiring possibilities is a society based on the best elements of national Australian tradition, the most important postulates of multiculturalism, and the needs and interests of the broad majority of the population. Such a political and cultural re-orientation would transcend any idea of nationalism, nation-state or simply imagined community.

The Australian traditions which should be re-asserted are not those of colonization or war, but those of the "fair go", that is of social justice for all. The image of Australia which should be brought back is that of the "workingman's paradise", though the racist and sexist aspects of this ideal would need to be worked through and modified.

The aspects of multiculturalism worth maintaining are the principles of cultural self-determination and of cosmopolitan identity. They must be linked to measures to meet the of specific needs of discriminated and disadvantaged groups, policies to overcome structural marginalization and labour market segmentation, and to combat racism.

Above all, the history of white racism and genocide against the Aborigines must become a central theme of education and public debate, and an accommodation with the Aborigines must be achieved through payment of reparations, Land Rights legislation, and a treaty. Steps must be taken to improve dramatically the economic and social situation of the Aboriginal population, not through welfare measures, but through making adequate resources available to Aboriginal communities and these being placed under their own control.

Any such strategy must be based on an attempt to re-define the basis of social organization, and to move away from a political emphasis on the 
nation-state. Our life today is determined as much by events on the local level, as by those on the level of world politics and economics. In Britain, it has been local politics which have provided hope in the wasteland of Thatcherism. There is no contradiction between attempts to build community and bring about change at the local level, political work in the national arena, and participation in world politics.

The Bicentenary could have been an occasion for celebration. The opportunity was thrown away by Australian political leaders' unwillingness to face up to the real issues and problems. Once the decision was taken to ignore Aboriginal demands for real expiation, the Bicentenary became a lost cause. It changed from something with potential social meaning to a public relations exercise. Bicentennial Authority propaganda let the cat out of the bag, by calling for the the inclusion of youth, women, ethnic groups, Aborigines and the handicapped in the celebrations. The conclusion was inescapable: only white Anglo middleclass men really had anything to celebrate in Australia; the inclusion of the rest was tokenism. If the Bicentenary had been concerned with helping to create an all-embracing society, it would have been based on real changes, designed to secure equality not only for the groups mentioned, but also to bring in others, whose marginalization makes them invisible for those in power: the unemployed, those living below the poverty line, the industrial casualties, the deprived.

The Bicentenary is yet another indication of how the concept of the nation has become ideological and exclusionary, failing to embrace most of the population. The group which wields power and benefits from it gets ever smaller. More and more of us are members of minorities. Building communality means taking the real situation in our cities, suburbs and country areas as a starting point, adopting political and economic forms which correspond with the needs and interests of the many groups who are voiceless at present, and working for change everywhere. We do not need a new ideology of nationhood. We need to transcend the nation, as an obsolete and increasingly obsolete relic of early industrialism. Our aim must be community without nation. 


\section{FOOTNOTES}

1 BENEDICT ANDERSON, Narrating the Nation, in: Times Literary Supplement, 13 June 1986.

2 Multiculturalism has other meanings too, which will be discussed later in this book.

3 ANDREW JAKUBOWICZ, State and Ethnicity: Multiculturalism as Ideology, in: J. Jupp (Ed), Ethnic Politics in Australia, Sydney: George Allen and Unwin 1984.

4 Australian Bicentennial Authority, Fact Sheet, no date, no place.

5 Australian Bicentennial Authority, How to Make it Your Bicentenary, no place, 1987.

6 How to Make it Your Bicentenary

7 How to Make it Your Bicentenary

8 DONALD HORNE, The Public Culture, London and Sydney: Pluto Press 1986, p.8.

9 This theory is developed in Benedict Anderson, Imagined Communities, London: Verso 1983. See also: Ernest Gellner, Nations and Nationalism, Oxford: Basil Blackwell 1983.

10 Although the idea is tempting: The French National Convention decided to restart history, by declaring the year of the abolition of the monarchy as year one of a new calendar, as Anderson points out in: Narrating the Nation...

11 HORNE, p.21.

12 RICHARD WHITE, Inventing Australia, Sydney: George Allen and Unwin 1981, p.viii.

13 "...it may be said that to all intents and purposes, the history of the British in this country is the history of Australia". J. Lyng, Non-Britishers in Australia, Melbourne: University Press 1935, p.1.

14 WHITE, Inventing Australia, p.83.

15 HUMPHREY MACQUEEN, A New Britannia, Penguin 1970.

16 WHITE, p.146.

17 See TOM NAIRN, The Break-up of Britain, London: Verso 1981.

18 MARIE DE LEPERVANCHE, Australian Immigrants 1788-1940, in: E.L. Wheelwright and K. Buckley, Essays in the Political Economy of Australian Capitalism, Vol. 1, Sydney: Australia and New Zealand Book Company 1975.

19 GELLNER, Nations and Nationalism, p.1.

20 GELLNER, p.1.

21 NIRA YUVAL-DAVIS, Ethnic/Racial Divisions and the Nation in Britain and Australia, Capital and Class 28/1986, p.92.

22 J.LYNG, Non-Britishers in Australia, p.1.

23 W.E.H.STANNER, The Australian Way of Life, in: W.V. Aughterson (ed) Taking Stock, Melbourne: Cheshire 1953, p.8.

24 WHITE, Ch. 10. 
25 AUSTRALIAN COUNCIL ON POPULATION AND ETHNIC AFFAIRS, Multiculturalism for All Australians: Our Developing Nationhood, Canberra, 1982, p.16.

26 AUSTRALIAN ETHNIC AFFAIRS COUNCIL, Australia as a Multicultural Society, Canberra, 1977, p.6.

27 P. W. MATTHEWS, "Multiculturalism and Education" in: Education News, Vol. 16, No. 10, 1970, p. 16.

28 David BARNETT, "Dividing Australia: How Government Money for Ethnics is Changing our Nation", in The Bulletin, 18 February 1986.

29 L. J. M. COORAY, "Multiculturalism in Australia: Who Needs It?", Quadrant, April, 1986, pp.27-29. 